British Art Studies

Issue 10, published 29 November 2018

Landscape Now

Cover image: David Alesworth, Unter den Linden, 2010, horticultural intervention, public art project, terminalia arjuna seeds (sterilized) yellow paint.. Digital image courtesy of David Alesworth.

PDF generated on 14 April 2022

Note: British Art Studies is a digital publication and intended to be experienced online and referenced digitally. PDFs are provided for ease of reading offline. Please do not reference the PDF in academic citations: we recommend the use of DOIs (digital object identifiers) provided within the online article. These unique alphanumeric strings identify content and provide a persistent link to a location on the internet. A DOI is guaranteed never to change, so you can use it to link permanently to electronic documents with confidence.

Published by:

Paul Mellon Centre

16 Bedford Square

London, WC1B 3JA

https://www.paul-mellon-centre.ac.uk

In partnership with:

Yale Center for British Art

1080 Chapel Street

New Haven, Connecticut

https://britishart.yale.edu

ISSN: 2058-5462

DOI: 10.17658/issn.2058-5462

URL: https://www.britishartstudies.ac.uk

Editorial team: https://www.britishartstudies.ac.uk/about/editorial-team

Advisory board: https://www.britishartstudies.ac.uk/about/advisory-board

Produced in the United Kingdom.

\section{Ajoint publication by}




\section{Contents}

Liquid Landscape: Southam, Constable, and the Art of the Pond, Stephen Daniels 


\title{
Liquid Landscape: Southam, Constable, and the Art of the Pond
}

\author{
Stephen Daniels
}

\section{Abstract}

Water, in its various forms-from rivers to clouds, and amphibious sites, from marshes to meadows-has long been an integral, perhaps characteristic presence in the landscape arts in Britain. Currently, water is emerging as a key element in a wider art practice and environmental imagination. This paper considers the presence of a particular, if overlooked, water feature, the pond, in the work of two artists: one contemporary and the other a historical English landscape artist, both of whom are attentive to a range of hydrologies. The first part considers the place of water in the "landscape stories" of the contemporary photographer Jem Southam, and the series on the pond at Upton Pyne in Devon. The second part addresses the "natural history" of John Constable's watery landscapes, and focuses on the place of Branch Hill Pond in his pictures of Hampstead Heath. The works of both artists maybe be located in a long-standing topographical tradition.

\section{Authors}

\section{Acknowledgements}

My thanks to Nicholas Alfrey for his input into this paper, and to Jem Southam for discussing his work during a field walk with both of us in October 2017.

\section{Cite as}

Stephen Daniels, "Liquid Landscape: Southam, Constable, and the Art of the Pond", British Art Studies, Issue 10, https://dx.doi.org/10.17658/ issn.2058-5462/issue-10/sdaniels 


\section{The Place of Water}

Water, in its various forms-from rivers to clouds, and in amphibious sites, from marshes to meadows-has long been an integral, perhaps characteristic, part of the landscape arts in Britain.

Currently, water is emerging as a key element in contemporary art practice, particularly in the extremities of its distribution, from floods to drought, connected with anthroposcenic narratives of climate change. Water levels in environmental scholarship, across the humanities and sciences, have been rapidly rising, with studies of hydrologies, in wide-ranging societies and spaces, framing larger cultural issues. A range of topics from modernity to citizenship, once largely inland matters, are now on the waterfront, materially and imaginatively. Liquidity has become a key word, in such phrases as liquid times, liquid history, liquid cities, sometimes with a wider implication of flow, material process, and circulation. Landscape itself appears more liquid as a field of inquiry, with rivers, coasts, and lakes overspilling into a world of wetlands, water worlds, and waterscapes. 1

It is then timely to consider the place of water in the landscape arts of Britain, to consider questions of natural and cultural history in the formation and representation of water features and hydrological regimes, and to address the relations of land and water, at the intersection of epic and everyday histories, of material and mythical worlds. This paper does so by focusing on a commonplace if often academically overlooked water feature, the pond, as it appears in the work of the contemporary photographer Jem Southam and the nineteenth-century painter John Constable. The paper considers the portrayal of ponds, in terms of local ecologies and economies of the sites portrayed, in the wider systems of water management, and in the larger, hydrographic imaginations of the artists. This paper takes its cue from a remark made by lan Jeffrey in an essay for Southam's 2000 volume: Rockfalls, Rivermouths Ponds. Jeffrey notes that the ponds in the volume "look cataclysmic" like meteor impacts or the flooded saps and mines in scarred battlefields of the Great War,

but they are probably just dug out, sometime in the last century by a man with a horse and cart ... like some of those figures you see in John Constable's paintings ... They are the kind of structures which fall almost out of sight below any of history's agreed horizons. 2 


\section{The Place of the Pond}

If ponds fall below the horizons of some of history's grander narratives, they have a key role in locally focused, natural, and topographical histories, both as named places, and as generic forms of water feature. A classic work in this tradition is Gilbert White's The Natural History of Selborne, first published in 1789, which has been in print ever since; it is an inspiration to generations of authors and artists, and significantly an influence on both John Constable and Jem Southam. $\underline{3}$

Along with particular trees and copses, crossroads and marker stones, ponds of various kinds are key landmarks in the parish of Selborne, named places such as Wolmer Pond and Bean Pond in the author's perambulations. Ponds in the parish have a variety of uses, for fishing and fowling, or watering livestock; they are arenas for observing detailed processes of natural and social history, such as the passage of migrating birds and the growth of aquatic plants which thrive on cattle dung on the bed; and they are places for pondering the relation of geology and scenery, for example, wondering why small ponds on porous chalk hills never fail, and why larger ones in impermeable clay valleys dry out. While emphasising detailed local knowledge, White also framed his parish in terms of a wider world, in prospect views, and systematic geography, mapping an expansive fluvial circulation, for a parish named after a small stream.

The Selborne stream makes one branch of the Wey; and meeting the Black-down stream at Hedleigh, and the Alton and Farnham stream at Tilford Bridge, swells into a considerable river, navigable at Godalming; from when its passes to Guildford, and so into the Thames at Weybridge; and this to the Nore into the German ocean. 4

As White put it in the Preface, he hoped to induce his readers to "pay a more ready attention to the wonders of Creation, too frequently overlooked as common occurrences ... towards the enlargement of historical and topographical knowledge." $\underline{5}$ The very first review of the book, in the journal The Topographer in 1789, found its attentive observations were made with "the precision of a philosopher ... not only the understanding is informed, but the imagination touched". $\underline{6}$

Ponds are conspicuous in a twentieth-century genre of landscape history made famous in the work of W.G. Hoskins, notably The Making of the English Landscape, as key sites in the origin and perpetuity of settlements, whether permanent or seasonal, or as more temporary features associated with 
particular periods. What made ponds visible-whether presently filled with water, passing silted depressions, or past desiccated hollows-was a combination of investigative technologies, current and former Ordnance Survey maps, new aerial photography, as well as motor car journeys, field walking and literary, etymological research. Ponds, in this literature, mark historical and temporal phases of landscape change, from never failing spring ponds as sources of origin, to mill and fish ponds, most dating from the Norman Conquest, to flooded gravel pits and mine workings in industrial districts. In this view, ponds are as much earthworks as waterworks-dug, damned, embanked, shaped, dredged, maintained, filled, and abandoned-linguistically connected to various forms of "pounding", penning, and enclosing, so as close to fields and village greens, as to pools and streams. Ponds with a rich array of regional names, such as flashes, meres, and mardles, emerge as key habitats and gathering places for all kinds of pond life, including local grazing and gossiping, long-distance wayfaring, and landscape observation. $\underline{7}$

\section{Jem Southam}

The contemporary photographer Jem Southam makes books of his work, a series of volumes characterised by texts as well as photographs, commentaries, and essays authored by Southam himself as well as by a number of other commissioned writers. Southam is a narrative artist, mindful of long-standing literary as well as pictorial traditions of landscape portrayal. Initially influenced by works in the 1975-1976 exhibition New Topographics at the International Museum of Photography, in Rochester, New York, which he restaged with Paul Graham in a reduced form at the Arnolfini Gallery, Bristol in 1981, Southam has subsequently acknowledged an older topographical tradition, in literature as well as photography. This focused more closely on the local detail and livelihood of landscapes, in often familiar places close to his home, patiently documenting subtle changes over time, in what he calls "landscape stories". Southam is mindful of the traditions of landscape history, including Gilbert White's local forms of attentive investigation, through repeated perambulations of a place, as well as the wider, regional and national surveys of his fellow Devonian W.G. Hoskins. In part, because of his familiarity with the structure and scenery of south-west England, with its mining history and exposed geology, Southam's landscapes are often mineral, and if post-industrial, are so in a way which recalls a deep industrial past. $\underline{8}$

Water is a key presence in Southam's work, water in its various forms: clouds, seas, rivers and streams, pools, ponds, and puddles. Water is part of a wider sense of flux and fluidity in landscape change-of making and unmaking, formation and dissolution-with a keen sense of how wider histories and geographies are implicated in a particular site. There is strong 
current, even a sombre undertow, of mythical as well as material history, of biblical flood, cosmic catastrophe, ruin and redemption, pollution and reclamation. So Clouds Descending, the title of his work on the industrial coast of Cumbria, is more than a matter of mountain mists, but is taken from the title of Wesleyan hymn, on the Second Coming, "Lo He comes with Clouds Descending". Water features as part of short, private stories as well as longer public narratives. A sequence charts the pool maintained by his painter colleague Mike Garton in ancient woodland near Exeter, first created when a tree had fallen, half-blocking a stream, and shown in an increasing state of abandonment after the painter dies, his apparatus of easel, poles, and string disappearing into the fabric of the woods. The kitchen sink in which Southam washes up looking over his family garden is photographed after many years of just looking, "sometimes feel[ing] the weight of the mortgage bearing down on me as I take in the prospect". $\underline{9}$

At the 2010 Art and Environment conference, at Tate Britain, Southam explained the role of large format cameras in charting a narrative field, in relation to a recent picture of the River Exe, on the contact zone between earth and water, a tale of the river bank, or rather a series of stories, revealing seasonal changes over a year and more.

Early on I started using a lens that rendered, even with this system, an exceptional degree of peripheral detail. This led me to pay more forensic attention to the myriad narratives that a view contained. In one photograph, for example, a thin line of ice follows the bank of the river, a large dog has recently made its way onto the soft sand of the bank, the river level has recently receded five or so inches leaving a small "tide" line of fine twigs, and two light stalks are all that remains visible from the profusion of towering and invasive Himalayan Balsam plants that grew here over the summer, while twisted through the lower hanging branches at various levels are clumps of organic material left from the earlier autumn floods, and on the higher branches of the alder trees that lean over the river hundreds of dark dots that are the remains of last year's fruit. $\underline{10}$

In his essay on Southam's book The River Winter, the journey along the banks of the Exe from late autumn to spring, Richard Hamblyn positions such local stories in grander global narratives: 
We forget that winter is the dry season ... after the freeze comes thaw and flood, as water returns to liquid movement and life.

Freeze thaw, flood: the great climatic cycles that carved the topography of the northern hemisphere, and which continue to shape the idea of winter that lies deep in our cultural imagination.

In Southam's anthology Landscape Stories (2005), the place and power of water shifts. The book opens with a selection from The Red River (1989), a series surveying the valley of a small tinning stream in Cornwall, running just seven miles to the sea, no more than a few yards across, coloured red by the minerals of this tin mining region. What the valley may lack in length, or the stream in width, is made up by the depth of the landscape, at 2,000 feet, Dolcoath Mine was one of the deepest in Europe, with numerous abandoned flooded shafts. The series depicts several valley profiles and sections, taking in many apparently waterless pictures-gardens, fields, buildings, interiors-of hard won habitation, in which the river is there by implication.

The middle selections in Landscape Stories are more explicitly hydrological, focusing on physical processes at contact zones of earth and water, in "rockfalls, river mouths, ponds" distributed across the coasts of southern England, from Kent to Cornwall and Somerset, defined by the English and Bristol Channels, opening to the Atlantic. Here is "a land that is unstable and unpredictable, constantly moving through different states and at varying speeds." The series "partly grew from a desire to imagine the Earth engulfed by water" and the rockfalls include tales of physical geographers who spend their lives observing the slow progress of rocks down mountains, "tiny rivulets of particles", opening up "the idea of the Earth as in a permanently fluid state".

The ponds appear at first sight to lie at a tangent to the rockfalls and river mouths that preceded them. Three are dew ponds, inland on dry hills, not connected to wider systems of flow-artificial features made by fabricating an impermeable layer (with materials including clay, soot, and straw) to trap rainfall, or snow melt, and which dry out seasonally and become abandoned as natural looking hollows. The pond at Brampford Speke may look like a dew pond, but actually isn't; and it is closely connected with the river system, one which I learned on a field walk with Southam, is part of the flood plain of the Exe, a depression scoured when the river overflows its banks in spate, which holds water as the river recedes (down a visible channel) and then dries out. It is photographed in five different years, filled with water at different levels, empty and growing with meadowland plants. Perhaps technically speaking, the feature at Brampford Speke is a pool rather than a pond, if, like the seasonal bay of a stream, such pools are used as watering places for 
livestock, and it puts the distinction in question, in a highly managed landscape in which it is often hard to separate natural, animal, and human modification.

The pond at Upton Pyne is another type: a flooded quarry of abandoned mine workings. The twenty-eight photographs show changes over five years: some part of dipytychs, surveying the water's edge, the banks, surrounding buildings and the track beyond; later ones looking out over the wider landscape. With its focus on habitation, in a former industrial landscape, it connects with the opening sequence of The Red River. Also the Upton Pyne sequence is a story of a settlement, told from an anonymous body of water on the edge of the village that for Southam "challenged the idea of what a village pond should look like."

\section{Upton Pyne}

Five miles north-west of Exeter, the village of Upton Pyne is now a farming, part commuter settlement, one, like many in rural Devon, with an industrial past. On the edge of the village, the pond is the flooded site of a former manganese mine, opened in 1770. In his book on Devon, W.G. Hoskins notes that this mine, and two smaller ones on the same lode,

supplied the whole country for many years. It was used first in the manufacture of Egyptian ware in the Potteries, and in purifying glass. Its later used in bleaching led to a considerable increase in output, some 2000-3000 tons being shipped annually from Exeter

in the early years of the 19 th century. $\underline{12}$

A visitor in 1810 noted how "the celebrated mine" had boomed from small beginnings, after "the best oxide of manganese that has ever been raised" was accidentally discovered by a person passing along the road to Exeter, its black matter seeping out of the surface of red sandstone gravels.

The estate owners, an old Devon family, the Northcotes, grew rich on the proceeds of leasing the mine to two Exeter merchants (one of whom is commemorated in the village church, along with the monuments to the Northcotes), and richer still as the lease expired and they resold amidst increasing demand. Briefed by the mine owner and supervisor, the "captain", the visitor walked down a winding path cut into a hillside to the foot of a fiftyfoot perpendicular rock, and a series of pillars left by opencast excavations forming an archway to two vertical shafts; winched down one another fifty feet, he heard men working further below but declining to go down the further fifty feet as conditions, in a mine not drained by pumps, were "thoroughly wet". The visitor reckoned "this single mine may be capable of 
supplying the whole island for a century yet to come", if it actually closed soon after, perhaps partly because of drainage problems. $\frac{13}{2}$ On later nineteenth-century maps, it is recorded as an "abandoned quarry", known locally as The Black Pit, before appearing as a bright blue pond on maps from the 1970s, after it filled with seepage, and run off, down the hill from the village, impounded by the dumping of spoil for new building.

When Southam first came across the pond at Upton Pyne, it was a tip for discarded household and farm waste and choked with fallen trees, and the land around was used to keep pigs and raise vegetables. Cycling past one day, he saw a man working at the edge of the water, one of the householders living by the pond, and stopped to talk and learn of his scheme to improve the place. This encounter prompted a series of works which recall the conventions of landscape art and of writing which was current during the period when the mine was in operation, particularly those based on repeated visits to a place to observe detailed natural and cultural changes, and to envision key moments in a longer-term narrative.

Some photographs have compositional echoes of Constable's Haywain, the whitewashed former mine captain's house framing one side of the pond, like Willy Lot's house at Flatford, a boat on the bank echoing that by the ford on the Stour. $\stackrel{14}{ }$ One view ranges further to include other houses of the village and the tower of the church. Developments on the other side, bordering a farm, are more utilitarian, including sheds with corrugated roofs. The series engages closely with the conventions of landscape design, in which the making of water features-including the refashioning of former horse pools, fish ponds, and flooded quarries-is a central motif. Time specific transformations scenes were central to Repton's art of landscape gardening, initially neat prospects fashioned from unkempt circumstances, but also records of more uncertain progress, and abandonment of precarious schemes, under pressure from wider social powers in the land and the forces of nature. 15

The first part of Upton Pyne surveys a man's efforts to transform the landscape into an "arcadian realm", burning and clearing, introducing ducks, geese, woodland glades, and banks of flowers. While his efforts remained unfinished, the task was taken up by others, if again with signs of hard won changes and defeats. As the boat changes position around the banks, so it gradually rots, sheds fall in, vegetation spreads, trees collapse, an orange plastic crate slips into the water (Fig. 1). All bear testimony to the attrition involved in such a human venture. However, during the second phase of work, a new energy and a more utilitarian vision did succeed in turning the pond and its surroundings into an extended garden, altogether a more welcoming sight. 


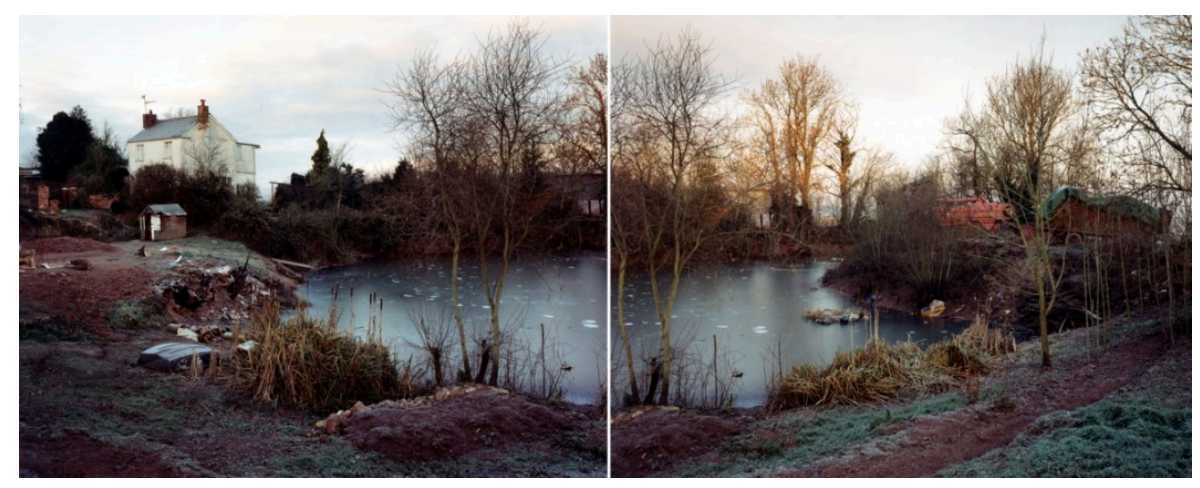

Figure 1.

Jem Southam, Upton Pyne (book 1 \#6\&7 Diptych), January 1997/2004, chromogenic dye coupler prints on Sintra mount t1206c, each $68.6 \times 86.4$ $\mathrm{cm}$. Collection of Charles Isaacs Photographs Inc. Digital image courtesy of Jem Southam.

The final part of the story pans away from water's edge to place the pond in "a wider geographical perspective". We look from a farm track over the countryside towards the Exe Valley, in the kind of sharp turn which landscape gardeners designed for carriage drives, to reveal a dramatic prospect of the countryside. Hoskins called the view "to the hills of Raddon ... over a countryside of the fertile red sandstones, at any time of the year ... one of the most satisfying views in all Devon". 16 The first picture of the track shows it smooth, newly surfaced, which over succeeding months becomes muddy and potholed, a large puddle forming in the centre (Fig. 2) echoing the pond, the entrance looking progressively more neglected, with a sign saying "Slow Down Please" falling down. 


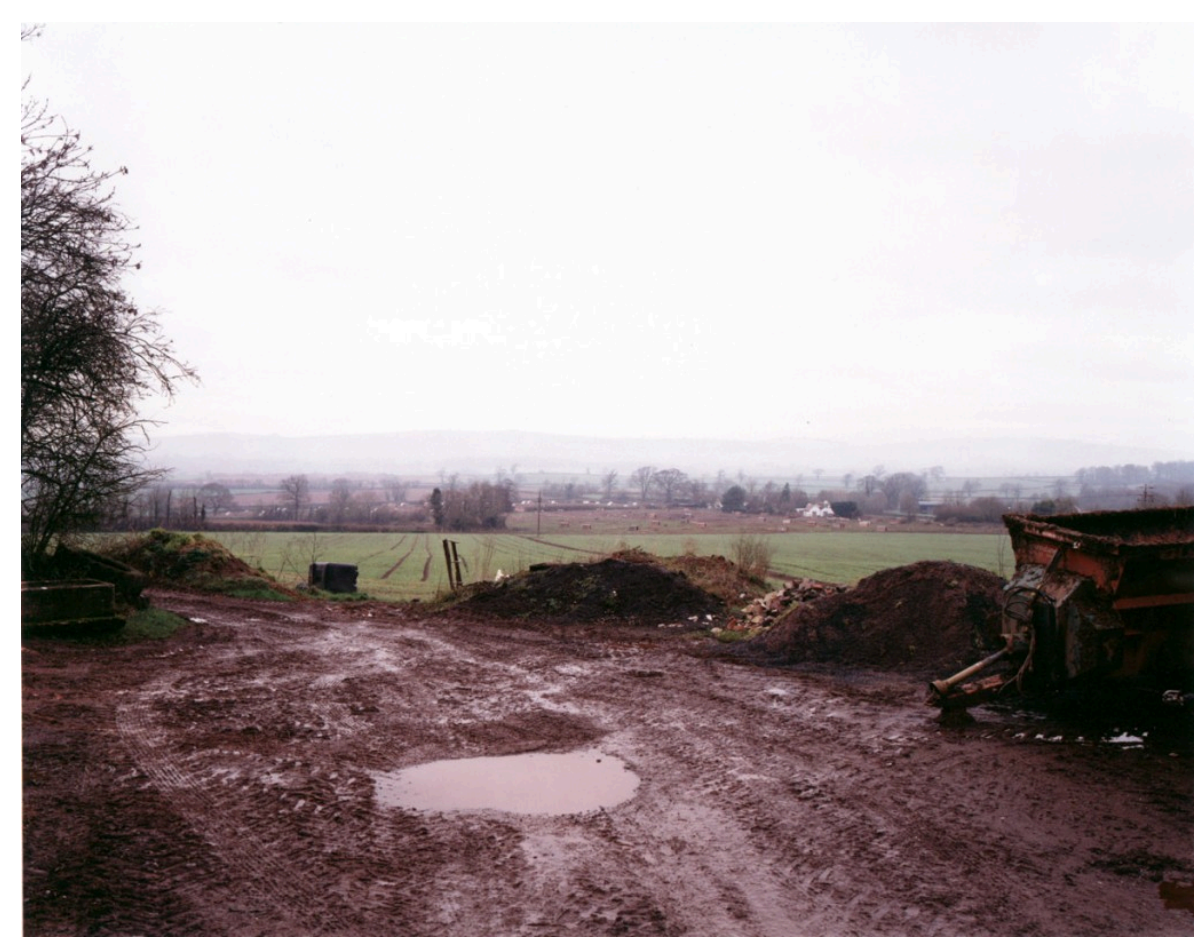

Figure 2.

Jem Southam, Upton Pyne (Epilogue \#2), 2004, chromogenic dye coupler prints on Sintra mount t1246c, $68.6 \times 86.4 \mathrm{~cm}$. Collection of Charles Isaacs Photographs Inc. Digital image courtesy of Jem Southam.

\section{John Constable}

Studies of the art of John Constable can scarcely step out of the water worlds of his landscapes, both in the sites he portrayed and in what he had to say about his art in letters, lectures, and reported conversations. So within Constable's catchment, defined by the rivers and coasts of south-east England, is a world of canals, fords, mill streams, sluices, rain showers, estuaries, breaking waves, and shipping channels, the vaporous atmosphere of clouds and dew, the moistness of pasture, as well as the half-submerged bankside plants and rotting wooden posts. Contributors to the recent Tate In Focus feature on Salisbury Cathedral from the Meadows, throw new light on the picture's hydrologies, the famous thunderstorm and rainbow, and the lesser known infrastructure of the meadows themselves, engineered for irrigation and drainage, and of the planned city itself, crossed by channels, built after it moved from its former site on the desiccated hill of Old Sarum. 17

Constable's approach was framed by ideas from the fields of natural theology, natural philosophy, and natural history, the traditional providential schema of the water cycle, the diagrams of modern meteorology, and the knowledge that comes from close, patient observation. Many texts combined 
local and global spheres of investigation, and different registers of natural knowledge. So Thomas Forster's Researches about Atmospheric

Phaenomena, with its systematic explanations of cloud formation and vision of meteorology as an advanced, worldwide form of knowledge (a passage which Constable marked in his copy), was supplemented by more local, proverbial Calendars of Nature. So that for Walthamstow in February 1812:

$16^{\text {th }}$ The Crocus in flower. Snowdrops abundant. I heard the sound of Frogs croaking in a pond by the side of Lea Bridge Road. $22^{d} A$ Thundershower with Hail to-day. $26^{\text {th }}$ The proverb of "February fill dyke" is made good today. The marshes of the Lea are quite flooded, and all the ditches stream with water. 18

Constable's engraver, David Lucas, recalled how the painter "explained to me if I may so call it the natural history" of Stratford Mill,

among his remarks were the following, that when water reaches the roots of plants or trees the action of the extremities of their roots is such that they no longer vegetate but die which explains the appearance of the dead tree on the edge of the stream. 19

In his lectures, Constable was similarly alert to the natural history on display in old master works. Of Poussin's “Winter-generally known as The Deluge... can there be greater proof of the effective power of landscape than that this portentous event should have been told by landscape alone", observing that the artist "has not allowed his imagination to wander from the Mosaic account which tells us of rain only. Human habitations, rocks, and mountains are gradually disappearing, as the water rises undisturbed by earthquakes or tornadoes." Ruysdael's Windmill, Winter "told a story" successfully. "The ground is covered with snow, and the trees are still white," and a mill "indicates a change in the wind." "The clouds are opening in that direction, which appears by the glow in the sky to be the south (the sun's winter habitation in our hemisphere) and this change will produce a thaw before morning." "Ruysdael understood what he was painting ... We see nothing till we truly understand it." $\underline{20}$

The humidity of Constable's art provoked a number of critical comments, for example, Fuseli's remark on seeing Salisbury Cathedral from the Meadows that the painter "makes me call for my great coat and umbrella" to the Literary Gazette's view that the painting revealed Constable as a "Neptunist", subscribing to the theory that water was the key agent of 
geological change. $\stackrel{21}{2}$ There was a larger cultural issue here-a European tradition of academic criticism that was suspicious of artistic effect of the damp climate and environment of Britain. Nicholas Alfrey has explored this in the reception of Constable's art in France, to pictures exhibited at The Salon in 1827 now known as the Haywain and View on the Stour. In the following year, in Revue des Débats, the critic Étienne-Jean Delécluze looked back on this landmark display to comment on the effect Constable had had on young French artists then, finding in what were evidently pictures of shallow, wellregulated waterways (forded by a cart, poled by a bargeman), and described as such in the catalogue, images of unruly, watery excess, "les marécages de M. Constable", Constable's marshlands, perhaps a treacherous terrain for the future of French art. 22

\section{Branch Hill Pond}

When Constable moved to Hampstead, he exchanged a familiar lowland hydrology of the eastern and southern coastlands, for that of urbanising, sandstone hills. Branch Hill Pond on Hampstead Heath features as a motif in a long series of Constable's works, exhibition oils and plein-air sketches as well as a print engraved by David Lucas. The series begins when Constable and his growing family took a series of summer lodgings in Hampstead from 1819 , initially near the west part of the heath, a few yards downhill from the tree-lined avenue of Judges Walk and views over Branch Hill Pond. The pond occupies different positions in the foregrounds of the pictures, left, right, and dead centre, in angles of view which encompass a range of features on and bordering the heath.

Branch Hill Pond was one of a number of ponds, of various kinds on Hampstead Heath, created at its many springs (at the junction of its cap of porous sandstone and underlying, impermeable clay) excavated for both sand and water supply from the eighteenth century, as part of the metropolitan expansion of London. The map in Topography and Natural History of Hampstead (1813, 1818), the first guidebook of the parish, authored by John James Park, picks out the arc of ponds in the watershed of the parish. Branch Hill Pond was fed by another pond higher up, Whitestone Pond, formed from the spring source of the Westbourne, which then flowed down towards London, through Kilburn, Bayswater and into the Thames at Chelsea. To the east, the Hampstead Water Company created a string of ponds from the Vale of Health, as reservoirs, from which water was piped by conduit as far as Tottenham Court Road. The ponds had multiple uses, the shallow ones for watering horses and livestock, the voluminous one at the Vale of Health was used for a main laundry site, although Park's volume warned that these deeper ponds "have been fatal to many incautious bathers, owing to the sudden shelving of their banks". 23 
In the process of pond construction, the marshiness of parts of the heath was drained and the landscape presented a clearer contrast of water and earth, with ponds enclosed from dry sandy soil, if new pits were liable to flood. Sand and gravel were carted out in vast quantities for brick making, path making, and road surfacing (spread as drying agent after heavy rain). There was then nothing archaic or rustic about the ponds in Hampstead; they were an integral part of its modern, metropolitan development, including a spate of new building in the place itself. Some ponds survived further nineteenthcentury changes, put to different uses; so the ponds of the Hampstead Water Company became an integral part of the Heath's preservation as an amenity, developed as open air swimming baths, if Branch Hill Pond did not.

Eventually filled in in 1889, its banks now form a hollow in a patch of grassed heathland surrounded by large trees and high-story buildings-a site that gives little sense of the spectacular scenes Constable portrayed.

A number of writings and pictures of Hampstead in the early nineteenth century note the raw and disturbed state of the landscape then, "the whole face of the heath is become so mutilated that the prospect of beauty is nearly destroyed", observed a visitor in 1806. But they also noted what Constable showed in his sketches, that a variety of colourful wild plants quickly colonised diggings, of bright red and yellow sand, and excursionists took to the dry pathways, terraced by excavations on each side, and picnickers to the hollows. Also there were efforts to preserve the trees which feature in many of these sketches, planted a hundred years before, remnants of avenues and groves, esteemed by radicals as well as conservatives as signs of resistance to speculative building. Such trees were landmarks in a new narrative which emphasised the controlled making and management of a polite, family friendly, professional man's suburb, with appropriate cultural amenities, and a great space, for the study of antiquity and natural history, in the minerals and fossils found in excavations, and in the exposed summits opening extensive views ranging over south-east England. 24

Among the reading matter that informed, or confirmed, Constable's studies of the heath was White's The Natural History of Selborne, recommended to him by his Salisbury friend John Fisher.

It is a book that would delight you \& be highly instructive to you in your art, if you are not already acquainted with it. I am quite earnest $\&$ anxious for you to get it, because it is in your own way of close natural observation: $\&$ has in it that quality, that, to me, constitutes the great pleasure of your society. 25 
Constable ordered a copy immediately, replying that, "the mind \& feeling which produced the 'Selborne' is such an [sic] one I have always envied", a "clear and intimate view of nature", "this book is an addition to my estate". $\underline{26}$ The edition Constable purchased, and which became the model for the work's popular success, was that edited by John Aikin, the Unitarian poet, essayist, and publisher, which made the work a more ecumenical text, appealing to a liberal view of landscape. Much of the antiquarian material of the original edition, dealing with manorial and monastic matters is cut, including long transcriptions in Latin, and the material added included a comparative Calendar of Nature, poems, and new illustrations. 27

Constable's most frequent compositions featuring Branch Hill Pond show the pond embanked against the road, with horses and cattle drinking, in one with bathers on the edge of the water (Fig. 3). The foreground is a steep sand bank, with a number of versions showing material being dug and carted out, heading for the road. In one, men are filling in depressions which had become waterlogged, a condition of excavation; another takes a view in the other direction, looking from the pond in the Vale of Health with a glimpse of the lower reservoirs descending to Kilburn. Excursionists ply sand tracks by Branch Hill Pond, and some lone spectators are silhouetted on the summit of sand banks. Houses feature beyond the heath, notably the one named as the Salt Box, in the modern title. In the final picture, one of the artist's last works, of 1837, is a windmill, usually reckoned to be transposed from a sketch of somewhere else, Suffolk or the South Downs, if Park's map of 1813 marked a windmill to the south, on Holly Bush Hill. 


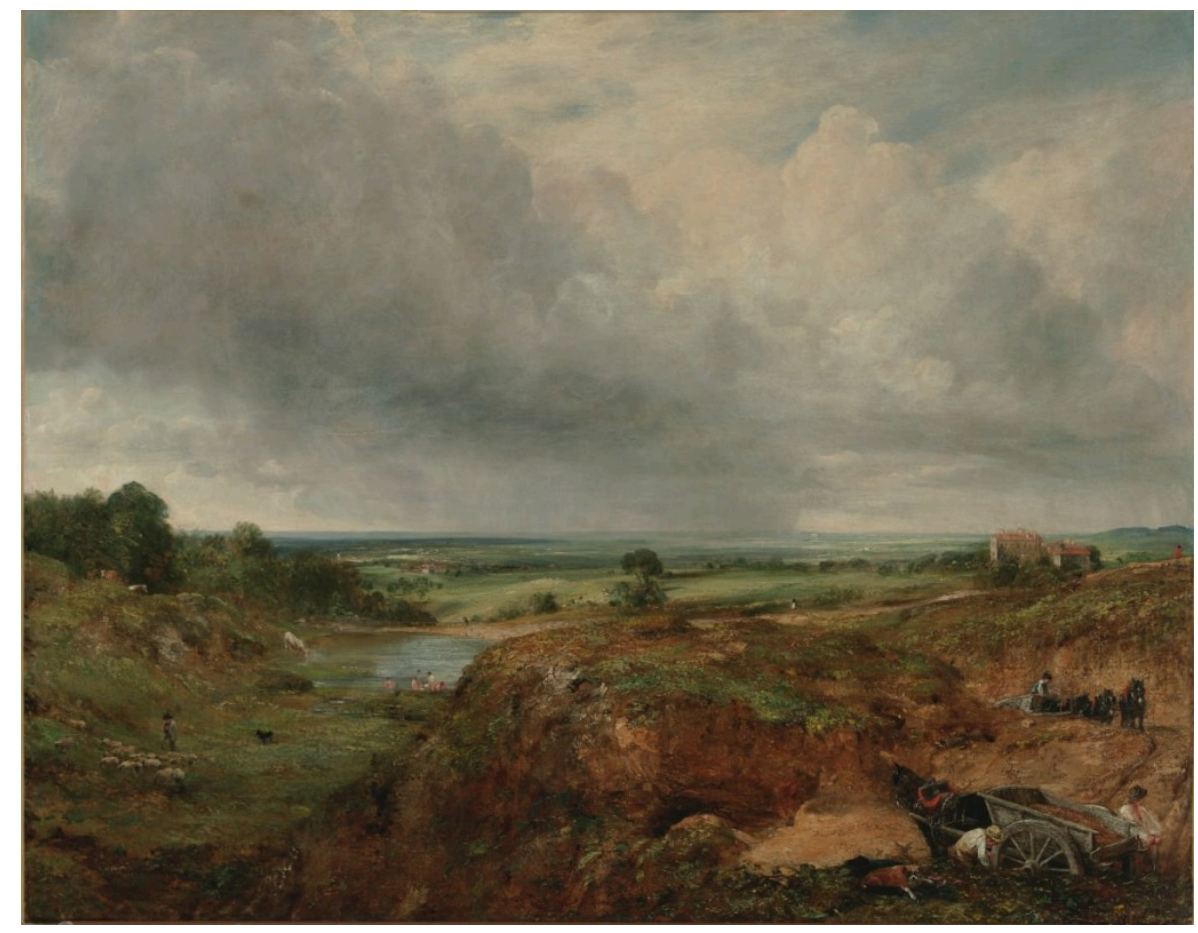

Figure 3.

John Constable, Branch Hill Pond, Hampstead, 1824-25, oil on canvas, 87 $x 102.87 \mathrm{~cm}$. Collection of Virginia Museum of Fine Arts, Adolph D. and Wilkins C. Williams Collection (49.18.4). Digital image courtesy of Virginia Museum of Fine Arts (CC-BY-NC).

The picture space in this view is bisected more or less equally between land and sky, and one of the functions of the pond is to mirror the sky, its particular formations of cloud and sunlight, and in some of the sunset sketches, illuminating the landscape (Fig. 4). The pond also describes the circularity, which is key aspect of this hilltop vantage point, for Constable valued the extensive 360 degree view. In a letter to Fisher, on a walk he took with his wife, he made a circular compass diagram of the "the panorama of this place", the cardinal points at Windsor and Gravesend, on the Thames, Dorking and St Albans on the chalk hills, adding that it had the "finest foregrounds-in roads, heath, trees, ponds". ${ }^{28}$ Like a guide to panoramas in London theatres, he pointed out to one purchaser of a Branch Hill view, entranced by the "fresh greens" in the middle distance, that here were the fields about Harrow and the villages of Hendon and Kilburn, and that the picture ranged further, that Windsor Castle was picked out on the horizon just to the north of a dark cloud and shower of rain. $\underline{29}$ 


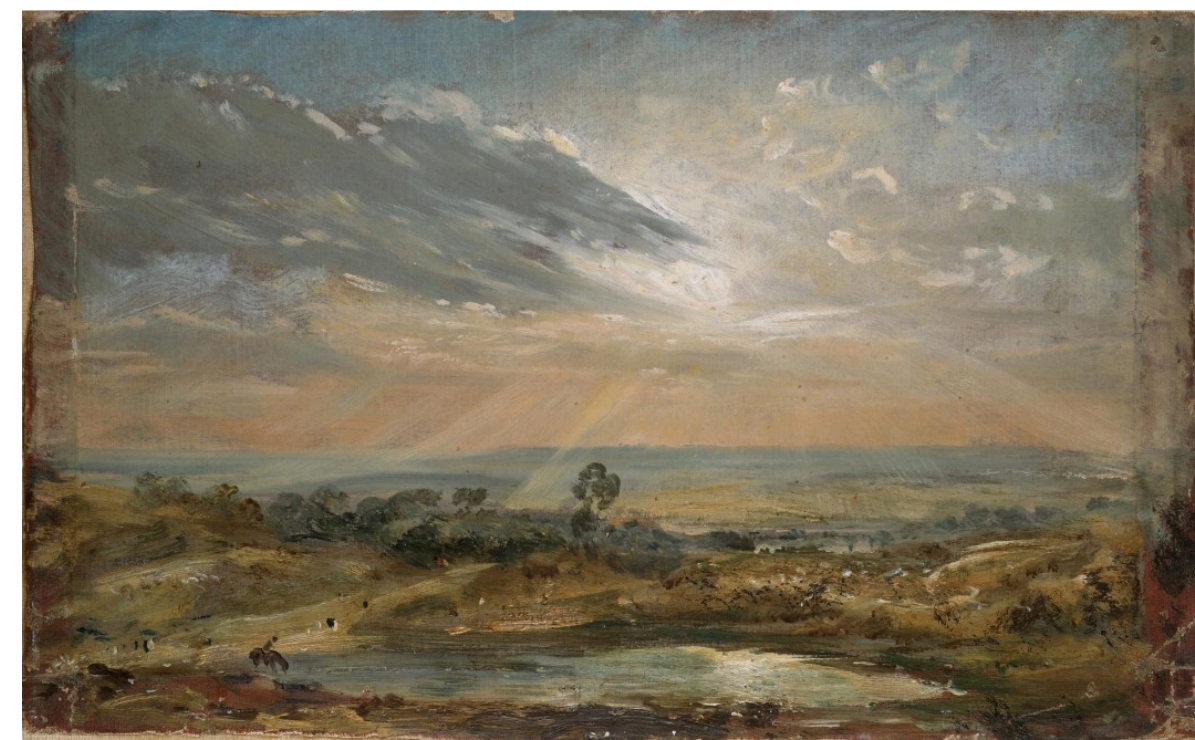

\section{Figure 4.}

John Constable, Branch Hill Pond, Hampstead, ca. 1821-22, oil sketch, dimensions unknown. Collection of Victoria \& Albert Museum, London (125-1888). Digital image courtesy of Victoria \& Albert Museum.

\section{Landscape and Place}

There are ponds aplenty in British art, if unlike other components of landscape with which they are closely connected, such as trees, cottages, gardens, farms, rivers, and roads, they have seldom been addressed in art historical writing as a motif, either as a functional feature or cultural symbol. 30 Ponds are often overlooked as commonplace-a local, lowly part of pictorial ensembles, hidden in plain sight, below the threshold of significance. For different periods and locations, Southam and Constable bring ponds into artistic focus, with an attention to the manifold particulars of these places, their lived experiences, as well as their detailed structure and surroundings.

The context for comparing their art over two centuries is a tradition of topography, in writing and pictures, that is presently being reclaimed in scholarship as a form of cultural representation. $\underline{31}$ Topography has never been a fixed, continuous genre; indeed, it has often been seen as too narrow in scope and too low in cultural esteem, before being periodically renovated, enriched, and transformed into an ambitious form of knowledge, for example, by a work like Gilbert White's The Natural History of Selborne. As White positioned Woolmer Pond and Bean Pond as both local landmarks, and sites in larger geographical worlds, so Southam and Constable similarly situate the ponds at Upton Pyne and Branch Hill. In a series of works, they 


\section{portray these ponds as arenas of detailed change, landmarks of memory, pivots of extensive panoramas, and places of reflection for wide-ranging, long-lasting questions on the making and meaning of landscape.}

\section{Footnotes}

1 Stephen Daniels, "On the Waterfront", in Francesco Vallerani and Francesco Visentin (eds), Waterways and the Cultural Landscape (Abingdon: Routledge, 2018), 19-28.

2 Ian Jeffrey, "The Earth and Us", in Jem Southam, Rockfalls, Rivermouths, Ponds (Eastbourne: Towner Art Gallery, 2000), n.p.

3 For a recent edition, which editorially not only situates White in his own time, but also explores subsequent responses, see Gilbert White, The Natural History of Selborne, edited by Anne Secord (Oxford: Oxford University Press, 2013).

$4 \quad$ White, The Natural History of Selborne, 8.

5 White, The Natural History of Selborne, 3.

6 Quoted in White, The Natural History of Selborne, 242.

1 See a key essay influencing Hoskins, titled "Ponds", in O.G.S. Crawford, Archaeology in the Field (London: Dent, 1952), 123-131. Ponds are also prominent in the more speculative landscape archaeology of Alfred Watkins, as key sites in extensive ancient trackways. See Watkins' popular text The Old Straight Track: Its Mounds, Beacons, Moats, Sites and Mark Stones (London: Methuen \& Co., 1925); and for a wider discussion, Stephen Daniels, "Lines of Sight: Alfred Watkins, Photography and Topography in Early Twentieth Century Britain". Tate Papers (Autumn 2006), https://www.tate.org.uk/research/publications/tate-papers/06/lines-of-sight-alfred-watkins-photography-andtopography-in-early-twentieth-century-britain. Accessed 1 March 2018.

8 Jem Southam in conversation with Andrew Nadolski, "Stories from the Land". On Landscape, posted 1 March 2013, https://www.onlandscape.co.uk/2013/03/jem-southam-interview/. Author's personal conversations with Jem Southam, notably in October 2017 and October 2018. Coincidentally, in 1992, Hoskins' ashes were scattered in the river meadows at Brampford Speke-the place of one of Southam's pond series, 1996-2000.

9 Jem Southam, Clouds Descending (Salford: Lowry Press, 2008); Jem Southam, Landscape Stories (New York: Blind Spot, 2005), n.p. See also Stephen Daniels, review of Jem Southam's A Raft of Carrots, Creative Camera 316 (June-July 1992), 35-39.

10 Quoted in Nicholas Alfrey, Stephen Daniels, and Joy Sleeman, "To the Ends of the Earth", Tate Papers 17 (2010), http://www.tate.org.uk/research/publications/tate-papers/17/to-the-ends-of-the-earth-art-and-environment. Accessed 6 June 2018.

11 Richard Hamblyn, "Winter", in Jem Southam, The River Winter (London: Mack, 2012), n.p.

12 W.G. Hoskins, Devon (London: Collins, 1954), 140.

13 Samuel Parkes, Chemical Essays, Principally Related to the Arts and Manufactures of the British Dominions, Vol. 2 (London: Baldwin, Craddock and Joy, 1823), 341-343.

14 Nicholas Alfrey, "Romanticism Gets Real”, Tate Etc 21 (Spring 2011), http://www.tate.org.uk/context-comment/ articles/romanticism-gets-real. Accessed 6 June 2018.

15 Stephen Daniels, Humphry Repton: Landscape Gardening and the Geography of Georgian England (New Haven, CT: Yale University Press, 1999).

16 Hoskins, Devon, 390 .

17 See the essays by Amy Concannon, John Thornes, and Charles Watkins, in Tate In Focus, https://www.tate.org.uk/ research/publications/in-focus/salisbury-cathedral-constable/the-painting. Accessed 6 June 2018.

18 Thomas Forster, Researches about Atmospheric Phaenomena, 3rd edn (London: Harding, Mayor and Lepard, 1823), 363. On Constable and Forster, see John E. Thornes, John Constable's Skies (Birmingham: University of Birmingham Press, 1999), 68-78.

19 Leslie Parris and Conal Shields, John Constable: Further Documents and Correspondence (London: Tate Gallery and Suffolk Records Society, 1975), 57.

20 R.B. Beckett, John Constable's Discourses (Ipswich: Suffolk Records Society, 1970), 52, 61, 64.

21 C.R. Leslie, Memoirs of the Life of John Constable (London: Longman, 1845), 109. Literary Gazette, 14 May $1831,315$.

22 Nicholas Alfrey, "The Marshlands of Constable", Tate Papers (forthcoming).

23 John James Park, The Topography and Natural History of Hampstead, 2nd edn (London: Nicols, Son and Bentley, 1818), 74

24 T.F.T. Baker, Diane K. Bolton, and Patricia E.C. Croot, “Hampstead: Hampstead Heath", in C.R. Elrington (ed.), $A$ History of the County of Middlesex: Volume 9, Hampstead, Paddington (London: British History Online, 1989), 75-81, British History Online, http://www.british-history.ac.uk/vch/middx/vol9/pp75-81. Accessed 11 June 2018. 
25 R.B. Beckett, John Constable's Correspondence VI; The Fishers (Ipswich: Suffolk Records Society, 1968), 64-66.

26 Beckett, John Constable's Correspondence VI; The Fishers, 64-66.

27 Gilbert White, edited John Aikin, The Works in Natural History of the Late Gilbert White (London: T. Bensley, 1802). Parris and Shields, John Constable: Further Documents, 45. On Aikin, see Stephen Daniels and Paul Elliott, "'Outline Maps of Knowledge' John Aikin's Geographical Imagination", in Felicity James and lan Inkster (eds), Religious Dissent and the Aikin-Barbauld Circle 1740-1860 (Cambridge: Cambridge University Press, 2012), 94-125.

28 Beckett, Constable Correspondence VI; The Fishers, 81.

29 Parris and Fleming Williams, Constable, 235-236.

30 For art in France, see the suggestive discussion of ponds in Greg M. Thomas, Art and Ecology in Nineteenth Century France: The Landscapes of Theodore Rousseau (Princeton, NJ: Princeton University Press, 2000), 23-27.

31 See particularly, the project hosted by the British Library, Picturing Places, https://www.bl.uk/picturing-places.

\section{Bibliography}

Alfrey, N (2011) "Romanticism Gets Real”. Tate Etc 21 (Spring), http://www.tate.org.uk/context-comment/articles/romanticismgets-real. Accessed 6 June 2018.

Alfrey, N. (forthcoming) "The Marshlands of Constable". Tate Papers.

Alfrey, N., Daniels, S. and Sleeman, J. (2010) "To the Ends of the Earth". Tate Papers 17, http://www.tate.org.uk/research/ publications/tate-papers/17/to-the-ends-of-the-earth-art-and-environment. Accessed 6 June 2018.

Baker, T.F.T., Bolton, D.K., andCroot, P.E.C. (1989) “Hampstead: Hampstead Heath". In C.R. Elrington (ed.), A History of the County of Middlesex: Volume 9, Hampstead, Paddington. London: British History Online, 75-81, British History Online, http://www.british-history.ac.uk/vch/middx/vol9/pp75-81. Accessed 11 June 2018

Beckett, R.B. (1968) John Constable Correspondence VI; The Fishers. Ipswich: Suffolk Records Society.

Beckett, R.B. (1970) John Constable's Discourses. Ipswich: Suffolk Records Society.

Crawford, O.G.S. (1952) Archaeology in the Field. London: Dent.

Daniels, S. (1992) Review of Jem Southam's A Raft of Carrots, in Creative Camera 316 (June-July): 35-39.

Daniels, S. (1999) Humphry Repton: Landscape Gardening and the Geography of Georgian England. New Haven, CT: Yale University Press.

Daniels, S. (2006) "Lines of Sight: Alfred Watkins, Photography and Topography in Early Twentieth Century Britain". Tate Papers (Autumn), https://www.tate.org.uk/research/publications/tate-papers/06/lines-of-sight-alfred-watkins-photography-andtopography-in-early-twentieth-century-britain. Accessed 1 March 2018.

Daniels, S. (2018) "On the Waterfront". In Francesco Vallerani and Francesco Visentin (eds), Waterways and the Cultural Landscape. Abingdon: Routledge, 19-28.

Daniels, S. and Elliott, P. (2012) “'Outline Maps of Knowledge' John Aikin's Geographical Imagination”. In Felicity James and Ian Inkster (eds), Religious Dissent and the Aikin-Barbauld Circle 1740-1860. Cambridge: Cambridge University Press, 94-125.

Forster, T. (1823) Researches about Atmospheric Phaenomena, 3rd edn. London: Harding, Mayor and Lepard.

Hamblyn, R. (2012) “Winter". In Jem Southam, The River Winter. London: Mack.

Hoskins, W.G. (1954) Devon. London: Collins.

Hoskins, W.G. (1955) The Making of the English Landscape. London, Dent.

Hoskins, W.G. (1973) English Landscapes. London, BBC.

Jeffrey, I. (2000) "The Earth and Us". In Jem Southam, Rockfalls, Rivermouths, Ponds. Eastbourne: Towner Art Gallery.

Leslie, C.R. (1845) Memoirs of the Life of John Constable. London: Longman.

Parris, L. and Fleming Williams, I. (1991), Constable. London: Tate.

Parris, L. and Shields, C. (1975) John Constable: Further Documents and Correspondence. London: Tate Gallery and Suffolk Records Society.

Park, J.J. The Topography and Natural History of Hampstead, 2nd edn. London: Nicols, Son and Bentley.

Parkes, S. (1823) Chemical Essays, Principally Related to the Arts and Manufactures of the British Dominions, Vol. 2. London: Baldwin, Craddock and Joy.

Salisbury Cathedral from the Meadows. Tate in Focus. http://www.tate.org.uk/research/publications/in-focus/salisburycathedral-constable/the-painting\#footnote59_ke04ey7. Accessed 6 June 2018.

Southam, J. (2000) Rockfalls, Rivermouths, Ponds. Eastbourne: Towner Art Gallery.

Southam, J. (2005) Landscape Stories. New York: Blind Spot.

Southam, J. (2008) Clouds Descending. Salford: Lowry Press.

Southam, J. (2012) The River Winter. London: Mack. 
Southam, J. (2013) "Stories from the Land". Jem Southam in conversation with Andrew Nadolski, On Landscape, 1 March 2013, https://www.onlandscape.co.uk/2013/03/jem-southam-interview/.

Thomas, G.M. (2000) Art and Ecology in Nineteenth Century France: The Landscapes of Theodore Rousseau. Princeton, NJ: Princeton University Press.

Thornes, J.E. (1999) John Constable's Skies. Birmingham: University of Birmingham Press.

Watkins, A. (1923) The Old Straight Track: Its Mounds, Beacons, Moats, Sites and Mark Stones. London: Methuen \& Co.

White, G. (1802) The Works in Natural History of the Late Gilbert White, edited John Aikin. London: T. Bensley.

White, G. (2013 [1789]) The Natural History of Selborne, edited by Anne Secord. Oxford: Oxford University Press. 


\section{Licensing}

The Publishers of British Art Studies are committed to supporting scholarship on British art and architecture of all periods. This publication is made available free of charge at https://www.britishartstudies.ac.uk. We ask users to identify the use of materials made available through this website and to provide an appropriate credit to the to the author and the publication, so that others may find and use our resources.

Except where otherwise noted, this work is licensed under a Creative Commons Attribution-NonCommercial 2.0 UK: England \& Wales Licence (CC BY-NC 2.0 UK). To view a copy of this license, visit https://creativecommons.org/licenses/by-nc/2.0/uk/ or send a letter to Creative Commons, PO Box 1866, Mountain View, CA 94042, USA.

The Publishers fully support the protection of intellectual property and are committed to complying with, and strictly adhering to, all applicable copyright law. In many cases, copyright or other proprietary rights may be held by individuals or entities other than, or in addition to, the Publishers. If a work or a photographic image is still protected by copyright, you must cite the relevant copyright information when using the image and comply with all other terms or restrictions that may be applicable to that material.

In some cases, exceptions to copyright that permit limited use of protected works without the permission of the copyright owner may have be applied. We are confident that we have carried out due diligence in our use of copyrighted material as required, but we apologise for any inadvertent infringement of rights.

Digital copies of resources are made accessible for research for one of the following reasons:

- they are in the public domain;

- the rights are owned by the Publishers;

- we make them accessible under an exception or limitation to UK copyright law, as outlined in the Copyright, Designs and Patents Act 1988 (as amended);

- we have permission to make them accessible;

- or, there are no known restrictions on use.

If you believe that we have made a mistake and wish for your material to be removed from our site, please contact us at copyright@paul-mellon-centre.ac.uk.

Please include the following information with your request:

- Name and contact information, including email address and phone number.

- Identification of the resource for consideration of removal. Providing URLs in your communication will help us locate content quickly.

- The reason for the request.

The Publishers respond promptly, normally within 21 business days. We may remove the resource from our site while we assess the validity of the request. Upon completion of the assessment, we will take appropriate action and communicate that action to you. 